measurement of radiant energy comparatively easy (Shelford 1929, Ch. XIV). Furthermore, the control of light by the use of darkness is quite prevalent in physiological studies and exclusive use of artificial lights is not acceptable in ecological investigations.

In order to have plants and animals under conditions of maximum sun exposure, the roof of the building should have a small garden space, a small air-conditioned glass-roofed house for use with animals (and plants under limited conditions). Due to the well-known high toxicity of a minute quantity of illuminating gas constituents, this should be on the main south wing near its south edge so that it is at least $100 \mathrm{ft}$. from any ventilators, which means that it should be planned from the beginning in the structure of the building. All ducts must be diverted away from spaces for biological use; entrance should be from the roof only. There should be no stairwell from the lower floors in this section of the roof.

\section{REFERENCES}

Bailey, F. 1950. Ultraviolet boosts egg production. Agr. Research Center (Beltsville release). Poultry Tribune, 56: 34.

Coblentz, W. W. 1945. Bioclimatic measurements of UV-solar and sky radiation in Washington, D. C., 1941-1944. Bull. Amer. Meterol. Soc., 26 (4) : 113-117.
Luckiesh, M. 1946. Applications of germicidal, erythemal and infrared energy. 463 pp. New York: D. Van Nostrand Company.

Marshall, F. H. A. and F. P. Bowden. 1934 The effect of irradiation of different wave lengths on the oestrous cycle of the ferret with remarks on the factors controlling sexual periodicity. Jour. Expt. Biol., 11: 409422.

Mercier, E. and G. W. Salisbury. 1941. Seasonal variations in hours of daylight associated with fertility level of cattle under natural breeding conditions. Jour. Dairy Sci., 30: 747-756.

Sabrosky, C. W., I. Larson, and R. K. Nabours. 1933. Experiments with light upon reproduction, growth and diapause in grouse locusts. Trans. Kansas Acad. Sci., 36: 298-300.

Shelford, V. E. 1929. Laboratory and field ecology. 608 pp. Baltimore: Williams \& Wilkins.

Shelford, V. E. 1951. Fluctuations of nonforest animal population in the upper Mississippi Basin. Ecol. Monogr., 21 (2) : 149181.

UNIVERSITY OF ILLINOIS, V. E. Shelford Champaign, Illinois

\title{
ECOLOGY AND THE SOCIAL SCIENCES
}

Distinction between ecology and the social sciences is not new (see Novikoff 1945) ; neither is a merging of their disciplines. But, as we appear to be entering a phase of merging (as shown in the number of recent publications on "human ecology," see Deevey 1951), a warning should be posted to remind us of the distinction.

This distinction is simple and basic. We have two groups of relations between organisms and environments. In both of these, any one relation exists only by virtue of an evolutionary past. The difference lies in the mechanism of this evolution.

Ecological relations are in a class with anatomy and physiology; they depend upon the physical inheritance of specific gene patterns. Genes influencing or causing particular relations are selected for or against by the same forces (natural selection) that affect all genes. Evolution in new directions must await the random and uncertain appearance of suitable mutations.

Sociological relations are in a class by themselves; they depend as a group upon the inheritance of a generalized gene pattern, but any one relation is inherited through culture. The latter is learned, can be modified, and need not be handed to the offspring. Selective forces include, for example, belief and persuasion, and evolution in new directions must await the appearance of appropriate ideas.

This distinction is not trivial. It precludes any consideration of homologies between the fields. Only analogies are possible, and it should be remembered that analogies do not increase information.

The two systems of forces, both shaping environmental relations, have produced many interesting analogies. A further alliance through a merging of labels can produce serious and widespread misuse of terms and concepts. Typical examples are the words "society" and "ecology," each well established in both fields. The ecologist uses "society" to describe behaviour patterns that are determined genetically; the sociologist uses "ecology" to describe spatial adjustments that are completely cultural. Even though the users of these terms may not be confused, some of the readers are sure to be misinformed. 
Because culture is absent in most species, and negligible in all except man, a study of the environmental relations except those of man includes no sociology. And because genetically determined ecology in man is vestigial, a study of the environmental relations of man includes no ecology (except, of course, applied ecology, man's use of the ecology of other species; see Darling 1951). This division both as to species and processes is fortuitous, and decidedly convenient.

Etymologically, there can be no barrier to the inclusion of the social sciences as a branch of ecology. If this is done, however, a word is then needed to identify that branch of ecology based on genetic evolution. The situation is not without humor; the ecologist, long accused of excessive word-making, is suddenly bereft of a name for his own field.

\section{REFERENCES}

Darling, F. F. 1951. The ecological approach to the social sciences. Amer. Sci., 39 (2) : 244-254.

Deevey, E. S. 1951. Recent textbooks of human ecology. Ecology, 32 (2) : 347-350.

Novikoff, A. B. 1945. The concept of integrative levels and biology. Science, 101: 209-215.

Frederick E. Smith
Zoology Department,
University of Michigan,
ANN ARBor, Michigan

\section{NOTES ON THE ROLE OF CRAWFISHES IN THE ECOLOGY OF REPTILES, AMPHIBIANS, AND FISHES}

Recently Penn (1950) pointed out that crawfishes are important in the diet of many poikilothermous vertebrates. Data from 108 papers were combined by him into tables and graphs indicating the extent to which certain creatures feed on crawfishes. I wish to comment briefly on Penn's article, to .cite additional bibliographic references, to present further instances of predation on crawfishes in the eastern United States, and to discuss other ecological roles played by these crustaceans.

Penn states that "it is surprising that .. two species of snakes subsist largely on crawfishes" (p. 653). From his graph (Fig. 3), it would seem that these two species are Natrix e. erythrogaster and $N$. septemvittata. The frequency of crawfishes in the diet of the former is shown to be $100 \%$. But from the accompanying chart (Table 4), it is seen that this conclusion is based on the stomach contents of only one specimen. Obviously, $N$. erythrogaster should have been omitted from the graph, especially since it feeds mainly on fishes, frogs, and salamanders (Blanchard 1925; Conant 1938; Ditmars 1907; Schmidt and Davis 1941).

Penn's graph for Natrix septemvittata is more meaningful, as it is based on the examination of 57 specimens. The feeding habits of this species, and the literature pertinent thereto, have been discussed by Wood (1949).

The inclusion of Anguilla rostrata, Ameiurus lacustris, and Semotilus bullaris in the graphs might also be misleading, for, of each species, only 2 or 3 stomachs were examined.

The feeding habits of reptiles often vary geographically and ontogenetically. For example, Penn indicates that the frequency of occurrence of crawfishes in alligator stomàchs is $87 \%$. This figure is based on 305 specimens from the Sabine National Wildlife Refuge in Louisiana. However, crawfishes were entirely lacking from the stomachs of 74 alligators collected at the St. Mark's Wildlife Refuge in Florida (unpublished MS. of E. R. Allen 1948). Mcllhenny (1934, 1935) did not find crustaceans to be important in the diet of the alligator at Avery Island, Louisiana.

Penn soundly concludes that crawfishes are extensively preyed upon by many vertebrates and that more intensive study is warranted in order to utilize the crustaceans to fullest advantage in wildlife management. Further evidence of predation on crawfishes may be gleaned from the following papers (arranged by predator species reported therein):

Micropterus salmoides floridanus (Hubbs and Allen 1943; McLane 1948).

Necturus m. maculosus (Bishop 1926).

Cryptobranchus alleganiensis (Swanson 1948). Amphiuma m. means (Brimley 1920, 1939).

Amphiuma m. tridactylum (Baker 1937; Chaney 1951; Parker 1937).

Rana clamitans (Babbitt 1937).

Natrix $r$. rhombifera (Minton 1944).

Pseudemys scripta troostii (Cahn 1937).

I have brought up to date the taxonomy of some of the papers listed above.

From personal experience I can add a few reptiles to the list of predators on crawfishes in the eastern United States. Thus, in the Oconalufty River at the Cherokee Indian Reservation, North Carolina, it was noted that recently captured water snakes, Natrix s. sipedon, often disgorged crawfishes. In Rae's Creek near Augusta, Richmond County, Georgia, another water snake, $N$. s. pleuralis, was found to prey frequently on these crustaceans. In northern Emanuel County, Georgia, a water snake, $N$. rigida, apparently subsisted entirely on small crawfishes, judging from 11 food-containing stomachs examined. 